\title{
Smith-McCort dysplasia
}

INSERM

\section{Source}

INSERM. (1999). Orphanet: an online rare disease and orphan drug data base. SmithMcCort dysplasia. ORPHA:178355

Smith-McCort dysplasia (SMC) is a rare spondylo-epi-metaphyseal dysplasia characterized by the clinical manifestations of coarse facies, short neck, short trunk dwarfism with barrel-shaped chest and rhizomelic limb shortening, as well as specific radiological features (i.e. generalized platyspondyly with double-humped vertebral end plates and liliac crests with a lace-like appearance) and normal intelligence. The clinical and skeletal features are similar to those seen in the allelic disorder Dyggve-Melchior-Clausen syndrome (DMC; see this term), but can be distinguished from this syndrome by the absence of intellectual deficiency and microcephaly in SMC. 